\title{
Belgeo
}

Revue belge de géographie

$3 \mid 2014$

Art(s) \& Espace(s) / Art(s) \& Space(s)

\section{Public art as conversation piece: scaling art, public space and audience}

L'art public en discussion. Reconsidérer l'art, l'espace public et le public

\section{Martin Zebracki}

\section{(2) OpenEdition}

\section{Journals}

\section{Electronic version}

URL: http://journals.openedition.org/belgeo/13381

DOI: 10.4000/belgeo.13381

ISSN: 2294-9135

\section{Publisher:}

National Committee of Geography of Belgium, Société Royale Belge de Géographie

\section{Electronic reference}

Martin Zebracki, «Public art as conversation piece: scaling art, public space and audience », Belgeo [Online], 3 | 2014, Online since 19 December 2014, connection on 20 April 2019. URL : http:// journals.openedition.org/belgeo/13381; DOI : 10.4000/belgeo.13381

This text was automatically generated on 20 April 2019.

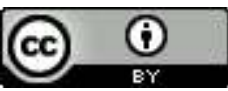

Belgeo est mis à disposition selon les termes de la licence Creative Commons Attribution 4.0 International. 


\title{
Public art as conversation piece: scaling art, public space and audience
}

\author{
L'art public en discussion. Reconsidérer l'art, l'espace public et le public
}

\author{
Martin Zebracki
}

\section{AUTHOR'S NOTE}

I am grateful to Sculpture International Rotterdam (SIR) for offering a spellbinding platform for my expert session at the 2012 International Architecture Biennale Rotterdam (IABR). The insights of the participants were of profound importance to developing the paper's argument. Whilst any errors remain my own, I am furthermore thankful for the anonymous referees' and editorial comments that have strengthened this analysis.

\section{Introduction: re-revving the public-art engine}

1 This practice-based paper attempts to further flesh out experts' lived experiences of the roles and (mis)uses of contemporary public art. Previous scholarship on public $\operatorname{art}^{1}$ has discursively reviewed - sometimes in an overly generalised mode - experts' faculty of thought about public art's manifold roles and (mis)uses, but falls short where it comes to how experts within the context of lived experience (Amin, 2002; Valentine, 2008) negotiate public art's socio-spatial scales along public space and audience. As such, this paper moves beyond representational public-art encounter. That is to say, the author has placed himself in the in-vivo context of expert knowledge exchange to query the sociospatial scales part and parcel of the art-public space-audience nexus.

2 Since the 1980s, policymakers and artists have been increasingly using public art as both rhetoric and tool to, among other things, put cities on the map in city-marketing and urban regenerating logic, play out political issues, make cities and regions more 
interesting to investors, aestheticise the environment, and promote social cohesion, community engagement, social movements and cultural empowerment (cf. Selwood, 1995; Hall and Robertson, 2001; Cameron and Coaffee, 2005; Remesar, 2005; Sharp, 2007; Zebracki et al., 2010; Stuiver et al., 2013). These aims involve oft-utopian physicalaesthetic, political, economic, social, and cultural-symbolic claims about what art "does" or should "do" to people over time and diverse city spaces, e.g. city-centre localities, outskirts, squares, neighbourhoods, and infrastructural and industrial sites (cf. ibid.). These public-art claims, foremostly produced by the experts or the "enablers" in publicart practice, have been subject to several critical studies to date (e.g. Mitchell, 1992; Roberts and Marsh, 1995; Deutsche, 1996; Miles, 1997; Senie and Webster, 1998; Lees, 2001; Kwon, 2004; Miles and Hall, 2005; Remesar, 2005; Sharp et al., 2005; Hein, 2006; McCarthy, 2006; Cartiere and Willis, 2008; Knight, 2008; Pollock and Paddison, 2010; Zebracki et al., 2010). Yet, there is a prevailing tendency to easy away from particular microgeographies of everyday public-art practice and in so doing generalise on public art's roles and uses.

In an idiosyncratic, multidisciplinary fashion, I build my argument on (auto-)ethnographic empirical insights gained at - and after - the interactive expert session Art, Public Space and the Audience, which took place in specific reference to the urban context of Rotterdam. This city harbours a rich tradition of public visual culture and is noted for its artistic interventions, landmark statuary and modern architecture the city brands itself as the "architectural capital of the Netherlands" (Rotterdam Marketing/VVV, 2007).

I provided the expert session at the invitation of Sculpture International Rotterdam (SIR) at De Dépendance: Centre for Urban Culture in Rotterdam, August 7 2012, during the International Architecture Biennale Rotterdam (IABR), a recurrent event that forms a spearhead of this city's cultural heritage policy. The design of the session consisted of three phases:

1. workshop including subgroup-based, semi-structured, discursive (i.e. both written and oral) brainstorm and mental-mapping exercises about the functions of experienced (un)successful existing public art in Rotterdam and potential (i.e. desired art) in Rotterdam's public space, and cities more generally (Figure 1);

2. presentations by the workshop subgroups and resulting interactive plenary debate (Figure 2);

3. a concluding lecture and synthesis of the workshop by the researcher and interactive plenary discussion (Figure 3).

5 In between, and after these phases, the event pursued discussions in the style of the World Café method (cf. Brown and Isaacs, 2005). This entailed small round-table as well as inter-group dialogues where participants seen as "guests" intermittently changed "host" tables to feed in preceding conversations.

SIR timely announced my expert session and 25 people, predominantly Rotterdam-based experts, put themselves forward for partaking in this session. The participants were artists; designers and landscape architects; scholars including art and architecture historians and critics; museum, art academy and visual arts centre directors; curators; cultural entrepreneurs; policymakers; advisers; politicians; and journalists. The majority of these local intelligentsia - notable and decisive figures included - held multiple roles, and their overall kaleidoscopic professional background and record of service proved to be thankfully fruitful in acquiring a grounded, microgeographical understanding of 
expert attitudes towards the roles and uses of art in public space in specific reference to the culturally dynamic fabric of Rotterdam ${ }^{2}$.

7 The expert session was continued by a lively discussion over e-mail and future regular meetings in the context of the - in Dutch so-called - Schouwploeg ("survey group") ${ }^{3}$. SIR established this ongoing think tank on art and public space, in which I have been taking part.

In the following, I first outline the paper's geographical argument with regard to three conceptual anchor points: art, public space, and audience. These three anchor points are interlinked by questions of socio-spatial scale. Based on the expert session and its "afterlife", these scales are taken on board with particular regard to issues of artistic production, the consumption of public space, and audience involvement, respectively. The presented empirical insights are reflected upon and discussed in the light of future research on lived public-art encounters. I wind up the paper by a metaphorical afterthought about building bridges between the diverse actors involved in public-art practice.

Figure 1. Expert session phase I: a workshop including subgroup-based brainstorm and mentalmapping exercises about the functions of art in public space.

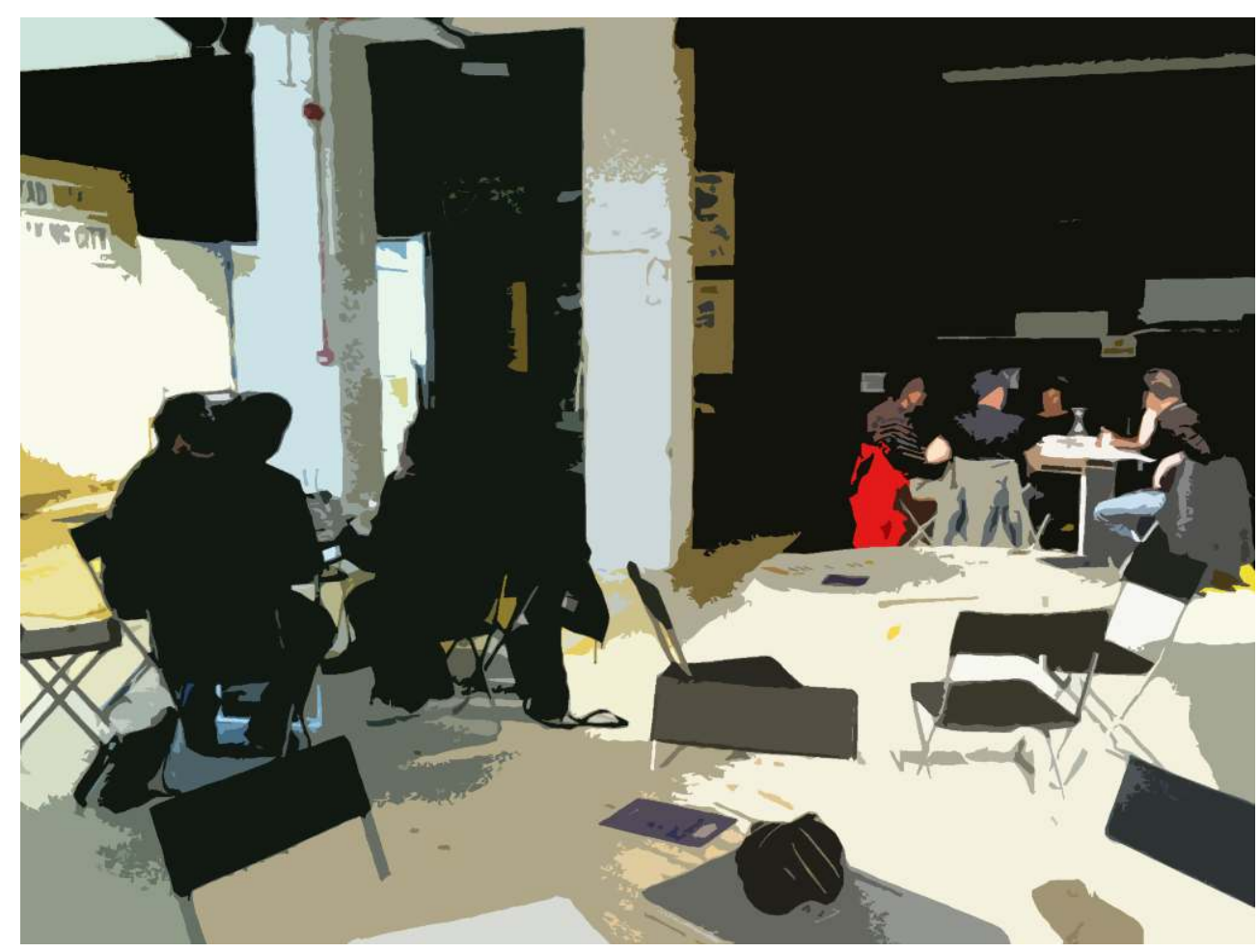

PHOTOGRAPH BY THE AUTHOR - IMAgE VISUALLY EDITED FOR CONFIDENTIALITY REASONS 
Figure 2. Expert session phase II: presentations by the workshop subgroups and resulting interactive plenary debate.

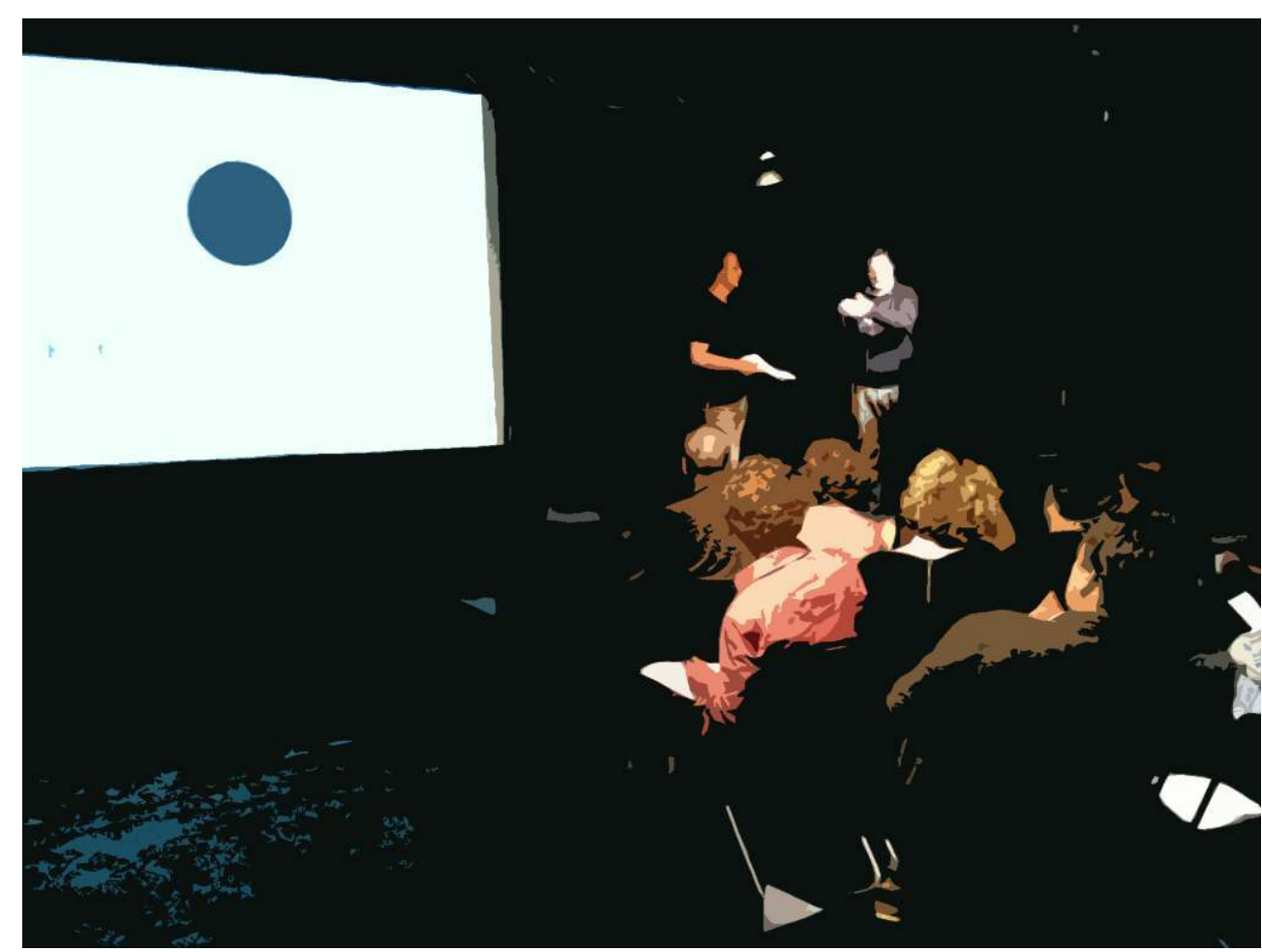

PHOTOgRAPH BY THE AUTHOR - IMAgE VISUALLY EDITED FOR CONFIDENTIALITY REASONS

Figure 3. Expert session phase III: concluding lecture and synthesis of the workshop by the researcher and succeeding interactive plenary discussion.

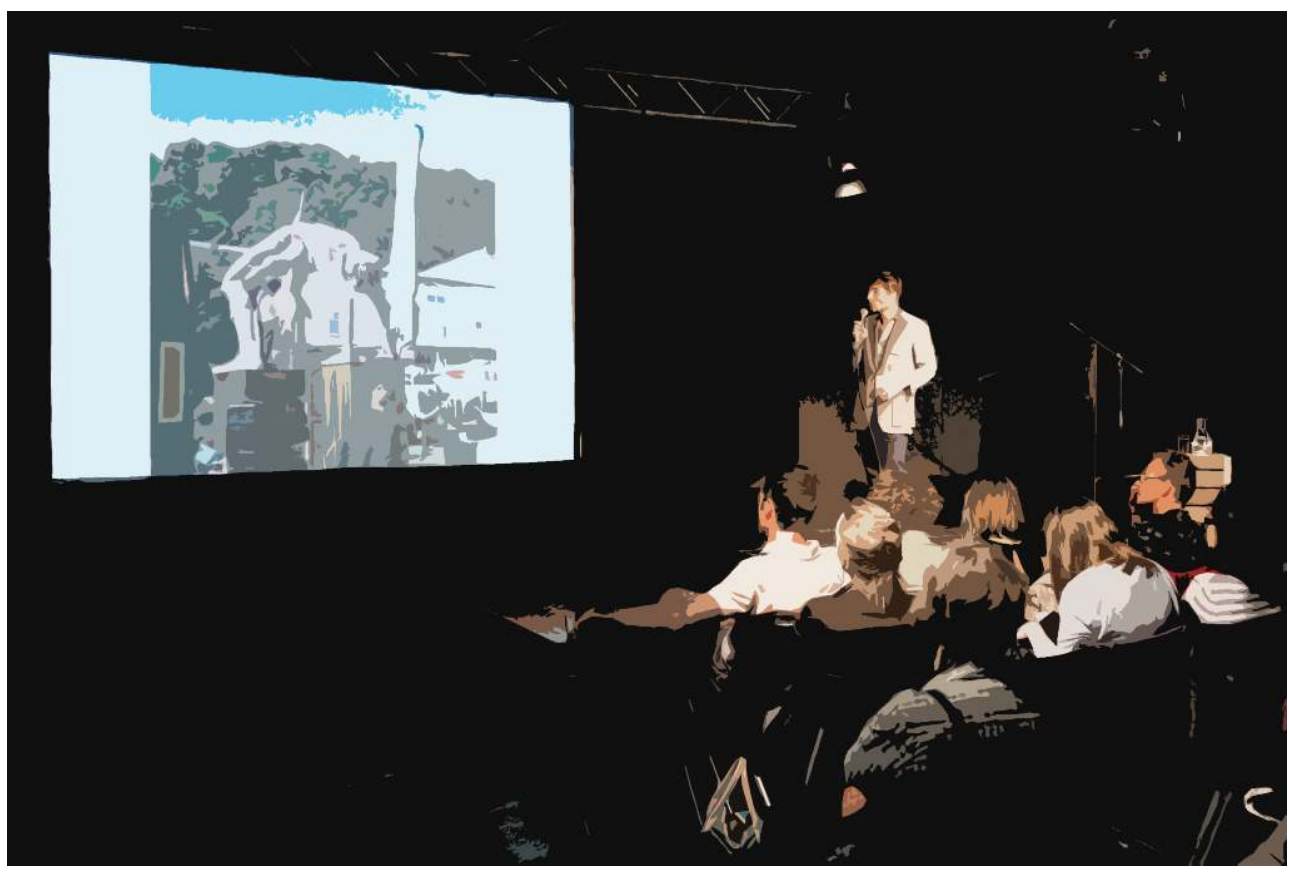

PHOTOgRAPH BY KONRAD ZEBRACKI - IMAgE VISUALLY EDITED FOR CONFIDENTIALITY REASONS 


\section{Art, public space and audience: imaging and imagining art in public space}

This paper is principally framed around scalar understandings of art, public space and audience and their interlinkages. Here, we may conceive of scale as the particularities of the (im)material dimensions of the artwork in and of itself and its proportions to environing conditions of the realm known as the open and freely accessible public space. Scale, furthermore, also pertains to the levels at which public-art-led interventions are planned, performed and experienced. Regarding the latter, we may identify a fluid degree of social engagement with public art, implicating that we can contemplate scale as a variable volume of such engagement.

There are limitations to the volume of social engagement. In theory we may argue that public art designates art on sites that are accessible to virtually anyone (cf. Miles, 1997; Hein, 2006). If public art is rendered as fundamentally created for and sometimes in tandem with its audience, the public at large - so all publics (cf. Zebracki, 2013) - is or should ideally be an involved party. Yet, there is exactly friction between this ideal discourse and the everyday experiences of social inclusionary, or exclusionary, practices of public art - these inclusionary or exclusionary geographies can be contrived, spontaneous, deliberate or unintended in nature (cf. Deutsche, 1996; Sharp et al., 2005; Pollock and Paddison, 2010).

In terms of the (im)material dimensions of public art, roughly, a relative distinction can be made between flagship i.e. prestige work, generally found in central city spaces, and community work that usually comes about in neighbourhoods (cf. Bianchini, 1992; Hall and Robertson, 2001; Grodach, 2008; Lacy, 2008; Zebracki et al., 2010). Particularly in the case of the former, art is occasionally injected from the design table into public space with scant (or even without) engagement with the immediate everyday users of that space (Hall and Robertson, 2001; Zebracki et al., 2010). Such "de-encounters" evidently may have detrimental implications for the volume of social engagement.

It is precisely in a socially limited or non-engaging context where the bird's-eye views of the creator and policy enabler prevail and where hence experts reason out and mobilise art in public space from beginning to end. This might be accompanied by a publicly perceived power-driven misuse of public art, particularly when it is motivated by authoritative self-interests. Following the rationale of this paper, it is compelling to map the provenance of - and problematise and deconstruct - the expert views of the contemplated roles and (mis)uses of particularly flagship artwork. This is a type of public art that is primarily managed by experts, which, in juxtaposition to community artwork, richly populates the city of Rotterdam 4 .

Considering the scale of public space an assembled, dialogical dimension of space and people, I am interested in how both are mediated through particularities of artistic manifestation. Here, reasoned from a Lefebvrian school of thought, the production of public space and hence public art concerns a social relational process (cf. also Massey and Rose, 2003). It is in this where public art intrinsically inhabits a socio-spatial reality beyond its reified dimension, that is material reality. In such real-imagined sphere - or "third space" (Soja, 1996) - the creators and enablers, i.e. experts, of public art endeavour to convey images of social space that may but do not necessarily fit in with the everyday 
use and experience of public space among other experts as well as diverse audiences of public art. Rather, those images might reflect their own institutional and abstractcosmopolitan multiscalar imaginations (cf. DaCosta Kaufmann, 2004; Popke, 2007) of the physical-aesthetic, political, economic, social, and cultural-symbolic roles and uses of art in urban communities (cf. Zebracki et al., 2010).

The encounters among public art's experts - as well as their experiences vis-à-vis those of public art's audiences - indicate a multifaceted, confrontational arena of "micropublics" (cf. Mouffe, 2000; Amin, 2002; Valentine, 2008). This means that social differences are - on occasion meaningfully - negotiated in "contact zones" (cf. Askins and Pain, 2011). Following Appadurai (1986), this involves interactions between subjects and materiality in mental or everyday socio-physical spaces and their interstices. Such process of agonistic pluralism (cf. Mouffe, 2000), meaning that it is embodied by power politics among co-emerging publics and critical counterpublics (cf. Warner, 2002) ${ }^{5}$, reveals the sheer public disposition of public art and its socially transformative potential. That is also to say that public art's material and performative capacities may provoke contacts and potentially meaningful (positively and/or negatively challenging) social interactions and learning moments in so doing (cf. Rancière, 2009). At the same time these capacities could reinforce or ignore dominant social norms and values. Public art, as such, actualises multifaceted agencies for various possible degrees of social engagement.

In the grounded purview of this study's expert-led design on lived experiences of public art, I employ the epistemological tenet of proxemics (cf. Lefebvre, 1991; Smith et al., 2009). This means that I attempt to probe into the microgeographies of experts' images and imaginations of the roles and (mis)uses of art in public space. These contemplated roles and (mis)uses of public art are - following analytical behavioural geography - essentially cloaked in messages that are sent, filtered and received (cf. Golledge and Stimpson, 1987) through the experts' senses as intertwined with norms, values and cognate attitudes. These senses are performed, reinforced or contested at multiple scales. These scales, intersecting the art-public space-audience nexus, range from the bodily experiential sphere to community mindsets and governmentalities at the (g)local level (cf. Hawkins, 2012; Zebracki, 2011, 2013). Empirically, the multiscalar experts' images and imaginations attended to three particular issues of scale that are elaborated hereinafter: artistic production, consumption of public space, and audience participation.

\section{Scaling artistic production}

The expert views overall critically addressed the scale of public-art production, more particularly the two-track public-art policy of the municipality of Rotterdam. On the one hand, this municipality produces flagship artwork, commissioned by expert committees that confer on what kind of art (in terms of, e.g., its creator/artist, shape, size, material or process) would be appropriate for specific places, audiences, and the spirit of the age in both the art world and society. On the other hand, Rotterdam Centre for Visual Arts sets up and facilitates neighbourhood-based community artwork, where the artist is usually explicitly invited to be genuinely amidst all local actors (including residents, entrepreneurs and any other civil-society stakeholders) and collaborate with them. A salient conversational topic regarding both tracks revolved around who should comprise the creational force, so to speak. Scale in this particular context should therefore also be understood in the cultural-geographical context of art-making. The debate, specifically 
regarding flagship artwork, embarked on whether the artistic producer should be an international artist of repute, a national artist or rather a local artist with an acknowledged strong personal commitment to the site of the intended piece of art.

Some experts stressed that site-specific ambitions should be the leitmotiv in the publicart process, as "the best artist for an artwork is the best artist according to the locality" (Respondent 12, artist and educational director at an art academy (male), 07/08/126). The workshop and plenary discussion raised issues about the form of desired artistic mobilities, hierarchies and diffusions and related levels of place attachments by the end users. These considerations above all touched on the following polarities, rather encompassing continua: permanent vs. temporary public art (i.e. public art all year round vs. seasonal art); top-down commissioned public art vs. underground art such as graffiti; artist-in-residence schemes vs. off-site artistic production; site-specific vs. generic (or "sterile") public art; figurative vs. abstract appearances; decorative vs. interactive work; art for central public city spaces vs. neighbourhood art in the "peripheral" outskirts. Thus, various interacting scales of place and scales of time play a part in understanding the provenance of public-art production, its current process and projected (confrontational) future. In this sense we may define public-art production as a "third space" (cf. Soja, 1996).

The experts broadly acknowledged that Rotterdam pursues these diverse public-art forms in hybrid spatial-artistic configurations. Here, saliently, some participants emphasised that the artists, policy enablers as well as everyday users of public space should ideally abandon functional-instrumental rhetoric to give free way to artistic production and expression. In this train of thought, we may aesthetically gauge the merits of public art at a phenomenological scale, where we should attempt to engage in an intuitive experience and gain the essence of public-art encounter. An architectural historian and ex-public-art curator explained such "free", phenomenological public-art production as follows:

"The landscape, the city, home, furniture, clothing, food, drink, language, text, image - and anything of value to speak of - that we have artificially accomplished are both functional and expressive. It is therefore art in the old meaning of the word, but not as we know it. A modern art view is reserved for forms that are mainly expressive and symbolic, whereof the functional origin is often concealed. In order to fully appreciate free public art we have to seclude time and space from everyday existence and give way to disengagement from functionality. Free public art precisely asks for this. We now have museums, gardens, sculpture parks and theatres that we visit for the sole sake of beholding art."

(Respondent 8 (male), e-correspondence 15/08/12)

This participant criticised the role of decisive actors in the art world and local authoritative policy fields in defining - or rather pre-establishing - the "function" of art in the everyday spaces of public life. Some experts made a plea for capitalising on disciplinary antagonism between museum and "outdoor" art spaces and to render and realise artistic expression through, if it may, an aesthetic-agonistic state of " Gesamtkunstwerk" ["total work of art", where arts disciplines are critically consolidated].

The workshop and plenary debates proved to be ambiguous about the extent to which artistic production should extricate itself from any (pre-)defined roles and uses of public art. Scaling public-art production, hence, is inherently tied up with interconnected power issues of artists' autonomy, local authorities' responsibility and audiences' democratic rights to space. This interplay involves scales of place, scales of time and scales of both 
aesthetics and ethics. These are thus important to our analytic understanding of how materials and social activities produce meaningful public-art encounters.

\section{Scaling the consumption of public space}

21 Another pertinent analytical scale of analysis concerns the consumption of public space. A key argument of the expert session arose around the extent to which agency should be given to artists but also to the various publics to allow for authentic and alternative voices to the top-down compartmentalised spaces of everyday life. In so doing, a more agonistic sphere might be created. Here, dominant public policies and prevailing consumerist appropriations of public space could be challenged and potentially subverted. A number of participants explicitly believed in such transformative power of certain praxes of public art. That is to say that public art, as an apparatus criticus, might have the radical potential to let people rethink and hence rescale the consumption of public spaces within material, social and symbolic dimensions. Concurrently, these creative practices, as also resonated by Rancière (2009), could act as inspiring critical and pedagogical window on public-art engagements in geographical contexts elsewhere. There was particularly much agreement in the debates regarding the crucial yet criticised role of the dynamic political and economic intermediaries in shaping and "consuming" the public artscape in its diverse material, social and symbolic dimensions - as conveyed by the following critical note:

"Through the loss of the tender support of the liberals, who harboured a patronising role of politics in the arts, the turn to a neoliberal outlook has been made. Now the old, dialogue-based socio-democratic system is down and out [...] This political turn has set its face against the social care for public space; or, worse still, a single notion or definition of a shared public space is now dismissed a priori. Public space doesn't exist any longer other than as an unorganised accumulation of private interests that warrant a hyperindividual space and [symbolic] "noncommunity". It is not a coincidence that the new political order, in its attempts to economise, relentlessly eliminated an organisation like SKOR [Foundation Art and Public Space; former Dutch public-art institution] that was fervently engaged in public space's design conditions."

(Respondent 12, graphic artist, curator and writer (male), e-correspondence 25/08/12)

This viewpoint heaps criticism on the current neoliberal formation - or rather reclaiming - of public space and life and some participants assumed attending detrimental influences on communal rapport. This quote reveals pure antagonism regarding consumerist mindsets that the participants also acknowledged to sense in the broader highly competitive neoliberal climate. As illustration, according to some experts, artists and urban arts agencies are forced to undercut the work of others, attain economies of scale and act as creative entrepreneurs, rather than enterprising creative persons, to put up a stubborn defence against economic competition.

Particularly, the expert debates gave vent to concerns about an increasing fragmentation of broadly supported interest in the artistic valorisation of the everyday public living environment. Nonetheless, in line with some participants, such fragmentation is inherent in public space. Through the lens of agonism, the "true" publicness of public space precisely exists by the grace of dissensus, a tug-of-war between ever more competing political and creative-aesthetic forces. As revealed by the discussion, these forces are not 
merely played off against each other (and hence dialectically consumed) in the city as such. They also implicate a radius of action beyond the local geography, thus involve consumption of other locales within urban and rural settings and virtual and augmented settings of dialogue - the latter are increasingly growing in terms of usership, spatial scope and social significance.

The debates, like so, revealed that grasping public-art practice entails multiscalar considerations of consumption processes that constitute and reproduce public space. On repeated occasions, participants strikingly referred to the controversial sculpture Santa Claus, situated in Rotterdam's city centre since 2008. In popular language, this work is termed the "Butt Plug Gnome", voicing the artist's criticism on the ceaseless "instant satisfaction" encountered in capitalist consumer society (cf. Zebracki, 2012). A number of participants, and myself, considered Santa Claus a contemporary textbook case to render the art-led consumption of public space not merely in terms of purely material appropriations. Such consumption was also - in the words of the previously quoted participant - considered a diachronic, socio-politically dissensual "Werdegang" [German term interpreted as "maturation" in the anthropological spirit of a rite of passage] at various levels of policymaking and social engagement:

"The unfolding of this sculpture is a sound expression of its public purpose. Santa Claus has sustained different ideological interpretations and acted as public subject for debate, including all accompanying commotion, negation and "hijacking", with a great deal of animation" (ibid.).

This participant's quote feeds in with an agonistic conception of micropublic. That is, public art enables contact zones between different people who hold various beliefs as well as mental and social "consumptions" of the public artwork. It is in such negotiation of social difference where (shifting) roles and transactions of power produce differentiated and possibly contesting agencies and knowledges. In line with Mouffe (2000), this precisely engenders a sphere for the creation, exchange and reinforcement of social norms and values but also for any alternative, radical democratic possibilities for social change. The latter may counteract hegemonic consumerist structures of society as embedded in public space.

\section{Scaling audience participation}

Experts' agonistic public-art experiences also revolved around the analytical scale of participation on the part of the audiences. That is, critical momenta in the interactive session pertained to the conjured extent to which the publics should be involved in the public-art process. A number of experts indicated that the decisive discussion about public art belongs to the domain of expertise of artists, policymakers, commissioners and the like. Others sensed that this would fall on deaf ears on the side of the audience and imply situations wherein the creators and enablers and the various publics are at crosspurposes. During a plenary discussion, an expert argued:

\footnotetext{
"Eventually it is politics as representative of the public that decides. The pressing question then is whether the taste and choice of the local decision makers is not gaining the upper hand in public-art practice."

(Respondent 14, cultural entrepreneur (female), 07/08/12)
}

We may consider this participant's quote in the light of power imbalance between those who decide and those who (passively) "watch". Agonistically, the very public and 
democratic nature of the public-art process would rather be disclosed and accentuated when there is a platform for social contact and exchange of pluralist ideas - as arduous and discording as they may be. In reply to the above quote, another participant stated:

"No, these [political] representatives are in their turn led by citizens, the rank and file of society, and especially the youth, the future citizenry. In this sense, the publics still have a say in decision making."

(Respondent 7, artist in public space (male), 07/08/12)

To the belief of some experts, this concerns a rather mechanical rendition of the democratic process of a participatory society and as such the quote buttresses the hegemonic division of social echelons in public-art encounter. A number of participants were substantially concerned with how public-art practice could advance broad public support and a psychological sense of "public ownership" towards particularly commissioned public art in order to avoid feelings of exclusion, disenchantment and resentment among the publics. They realised that further explorations should be made regarding novel and potentially site-specific channels of community participation in public-art practice, boosting citizenship beyond "voting" procedures and cosmetic consultations. As such, the locally ruling actors in the urban polity may encourage actual grassroots involvement and draw in lived audience experience in aid of fostering mutual respect. Without such involvement and respect those authorities would, as articulated by one of the respondents, "live in a fool's paradise" (Respondent 16, historian and director of local arts institution (male), 07/08/12).

The debate intimated that it is rather challenging to generally as well as specifically delineate audiences and accordingly pursue fully socially inclusive public-art policies. This is unmistakably depending on the particular features of the public artworks. A few experts stressed the relative, dual positions of the creators/enablers and publics, as in some participatory community art the producer and "consumer" can take up the role of each other. On the ontology of the audience, one of the participants wondered: "who is the public? Does it include passers-by, residents, visitors, ...? [...] Well, the public is basically everyone who is in public space" (Respondent 19, arts adviser (female), 07/08/12). In this sense, public art is thus a matter of reciprocal encounter with both the anywhere-present subject and object.

30 As encounter ranges between human's positive and negative experience, participatory and refraining behaviour, attentive and unheeding attitudes, etc., it does obviously not mean that public-art encounter possesses the same level of engagement for everyone. Some experts, moreover, argued that public appreciation of public art is not merely linked up with the degree of audience involvement. Positive public appreciation, according to them, could especially be manipulated by the (alleged) ephemeralness of public art. By referring back to the Santa Claus example, one of the experts commented:

"This artwork was initially proclaimed a temporary artwork, which eased acceptance among the Rotterdammers. Since it was brought to light that this artwork faced an enduring future it met with more and more resistance. At the same time Santa Claus grew into a city symbol that a considerable share of the local population took to their hearts."

(Respondent 24, art critic (female), 07/08/12)

Hence, according to some experts, the audience responses were reserved or even adverse at the artwork's microscale. But at the wider scale of urban society the audience seemed to mentally adopt the artwork's symbolic spirit. The above quote was supported by another expert who contended that Santa Claus's "iconic symbolism is considerably more 
salvable and unlocks much more to the broad public than abstract, discursive "art-art" (Respondent 8 (male), e-correspondence 15/08/12), while acknowledging that this artwork's deep-rooted codes also speak to the esoteric audiences of the art world. Santa Claus, thus, holds the agonistic agency to address various audiences and trigger various social engagements. For some experts, the work's deeper art and cultural codes rather embody a shade of patronisation towards audiences with differently informed cultural capitals. Some participants in the debates, nonetheless, mainly conceived of Santa Claus as a landmark public-art piece that, in the vein of McLuhan (1964), concerns a "warm", getat-able medium. That is to say, it would promptly fire the audience's imagination without imposing the expectation on this audience that it should concern itself with serious contemplative engagement regarding the legibility of the work's artistic-aesthetic and social subtexts.

\section{Reflections and discussion}

This paper has discussed experts' lived experiences of public-art production, the consumption of public space and audience participation along scales of place, time and aesthetics. The aesthetic practice of social public-art engagement, as enveloped in the expert event, might let us think about inter-subject and subject-object formations over different places and times. Public-art encounter may implicate a pedagogical process crucial to making contact with the "other" and to see, embody and organise the everyday living environment from different and reciprocally challenging vistas. Thus, public art can provide the agency to mediate social differences and relationships and as such various and potentially conflicting standpoints. Some fundamental questioning pointers in the public-art process are: who should produce public art and for whom? How should the artwork look and be like? For which public space should it be designed? To what extent and how should the various publics be involved in the public-art process?

The lively participatory, expert-led brainstorm and mental-mapping exercises, the interactive plenary debates and presentations and the World Café dialogues demonstrated as useful non-representational methodologies and pedagogical armamentaria to steer a middle course among the diverse socio-cultural, professional and disciplinary backgrounds and learning curves of the participants and myself. My observation during and ensuing from the live interactions was, as also acknowledged by some participants in situ, that agonistic thoughts about public art's essential environmental properties and added values characterised the conversation. That is to say, various beliefs about public art's meanings and capacities (in regard to, e.g., enhancing social relationships and wellbeing and whether it is intrinsically "good" for people and their living environment, etc.) were deconstructed at different socio-spatial scales. And in public-art practice we should attempt to pursue such critical attitude in a systematic, sustained way.

Depending on specific circumstances, e.g. the local socio-cultural and political dynamism and involved power constellation of actors, some experts furthermore critically acknowledged that public art is not always the right tool of - or even "solution" to restructuring and revamping everyday living spaces. Thus, on some occasions, there might be a plethora of other and more productive ways of physical interventions and social engagements. Hence, I argue that we are challenged to explore alternative roads to creative impact beyond any monopolised discourses within public-art practice. Here we 
may think of (counter)alternatives in the contexts of the design of urban parks and greens, sport events, discussion and interest groups, neighbourhood associations, and civil-society and professional organising.

I conveyed this critical challenge to the arts connoisseurs in the plenary discussion. This resulted in a somewhat heated and confounding debate about public art's raison d'être and particularly the perceived and desired extent to which the publics are or should be involved in public-art practice, also beyond community artwork. One of the experts, in a plenary e-mail to all participants the day after, retrospectively described the setting of this debate as a microcosm of local public-art practice - in allegorical reference to the influential German Bildungsroman The Magic Mountain (1924) by Thomas Mann:

"This was an occasionally hilarious, exasperating but fascinating struggle between Mr Lodovico Settembrini and the Jesuit Leo Naphta [referring to the audience and researcher in their relative roles during the debate]: the freemason with enlightened ideas face-to-face with the scientific thinker who wants to establish a universal religious society based on Brotherhood. In our debate these roles changed more than once. The struggle took place in the timelessness of the blinding snow and at the sanatorium in the Swiss mountains where people with severe lung conditions walked next to the dreamers who feigned grave illnesses [...] The struggle between Settembrini and Naphta, first carried on by words, eventually escalated into a duel with weapons, whereupon Naphta, owing to doubt and ire, shot himself in the head."

(Respondent 10, public-art adviser and curator (female), e-correspondence 08/08/12)

On precisely audience involvement and socially inclusive citizenship in public-art practice, I argue that future research should dedicate itself more strongly to inquiring into the intended and envisaged (in)appropriate and (un)customary socio-spatial effects and visceral affects - of public art towards its diverse publics. Expert-led public-art policy might build upon insights and empiricisms gathered in multisectoral working teams. Here the challenge is to buckle down to the experiences and socio-spatial belongings of the diverse publics, also by drawing them in brainstorm, design and planning-support sessions customised to the diverse social worlds of both the expert and audience. Multisectoral and audience-informed public-art practices can be construed into broadly grounded and transgressive expert public-art knowledges - in lieu of "me"-narratives. Those expert knowledges obtained in an interface with the publics, in their turn, might translate into multidisciplinary research that is in reciprocal feedback to policy and practice. As such, public art is an ongoing and multiscalar conversation piece that peruses and twists into ever-changing comprehensions.

\section{Afterthought: building bridges}

I put forward that building bridges is a fundamental, unfolding and continuing sociospatial challenge when art enters the public sphere. At a microscale, I took up this underlying challenge during my self-convened expert session Art, Public Space and the Audience. This session acted as a platform to interact with experts-as-researchers within but also beyond the context of the academy. The participants in this session ruminated over the (potential) mutual impacts of public art on its diverse places and publics. The microrealities of the participants' engagement and involved expert language and expressions revealed a rich conceptual and transgressive complexity. From their different backgrounds, the participants argued about the nexus of art, public space and the 
audience in the workshop and emanating plenary debates. Characteristic of the gist of the expert session were the co-occurrent and altering common grounds, differences, agreements in disagreements, dissonance in harmony, differences within the different, thus various conformities and ambiguities and, in sum, agonism: a state of dissensus (cf. Mouffe, 2000) in experiences and attitudes towards what art "does" to people and places over time. This cacophony of voices is illustrative of the everyday practice of public art, which places itself in the service of, so to speak, the spatially unexpected or unplanned of commonplace life.

The transdisciplinary and oppositional views of public art's roles and uses and connected socio-political power mechanisms which passed in review during the expert session got the reasoning going about public art in terms of a public "disorder" - as imparted in the diurnal chores of multiscalar governance and policy and within the multifarious mundane social practices of the users of public space. Such reasoning does not follow a clear-cut, straightjacketing principle of logic, and might rather disturb day-to-day realities pursuing such principle. Public art concerns a micropublic treasure-house - or rather conundrum - of multiscalar social encounters in ordinary and meaningful contact spaces (cf. Amin, 2002). Public art, therefore, acts as critical pedagogical window (cf. Ranciére, 2009) on the socio-relational production of public space more broadly and the role of the enabling polity as well as audience in (dis)equilibrating the artscaping thereof. If the "inter-esse" - i.e. "between-being" - between the enablers and audiences of public art genuinely steps into the limelight and becomes the product of transparency, plus also the lack thereof, can we (still) tell between whom we want, may and should build bridges?

\section{BIBLIOGRAPHY}

AMIN A. (2002), "Ethnicity and the multicultural city: living with diversity", Environment and Planning A, 34, 6, DOI: 10.1068/a3537, pp. 959-980.

APPADURAI A. (ed.) (1988), The social life of things: commodities in cultural perspective, Cambridge, Cambridge University Press.

ASKINS K. \& PAIN R. (2011), “Contact zones: participation, materiality, and the messiness of interaction", Environment and Planning D: Society and Space, 29, 5, DOI: 10.1068/d11109, pp. 803-821.

BIANCHINI F., DAWSON J. \& EVANS R. (1992), "Flagship projects in urban regeneration", in HEALEY P., DAVOUDI S., O'TOOLE M., TAVSANOGLU S. \& USHER D. (eds.), Rebuilding the city: property-led urban regeneration, London, E. \& F.N. Spon, pp. 245-255.

BROWN J. \& ISAACS D. (2005), The World Café: shaping our futures through conversations that matter, San Francisco, Berrett-Koehler.

CAMERON S. \& COAFFEE J. (2005), “Art, gentrification and regeneration - From artist as pioneer to public arts", International Journal of Housing Policy, 5, 1, DOI: 10.1080/14616710500055687, pp. 39-58.

CARTIERE C. \& WILLIS S. (eds.) (2008), The practice of public art, New York, Routledge. 
DACOSTA KAUFMANN T. (2004), Toward a geography of art, Chicago, University of Chicago Press.

DEUTSCHE R. (1996), Evictions: art and spatial politics, Cambridge, The MIT Press.

GOLLEDGE R. \& STIMPSON, R. (1987), Analytical behavior geography, Beckenham, Croom Helm.

GRODACH C. (2008), "Museums as urban catalysts: the role of urban design in flagship cultural development”, Journal of Urban Design, 13, 2, DOI: 10.1080/13574800801965742, pp. 195-212.

HALL T. \& ROBERTSON I. (2001), "Public art and urban regeneration: advocacy, claims and critical debates", Landscape Research, 26, 1, DOI: 10.1080/01426390120024457, pp. 5-26.

HAWKINS H. (2013), "Geography and art. An expanding field: site, the body and practice", Progress in Human Geography, 37, 1, DOI: 10.1177/0309132512442865, pp. 52-71.

HEIN H. (2006), Public art: thinking museums differently, Lanham, AltaMira.

KNIGHT C. (2008), Public art: theory, practice and populism, Oxford, Blackwell.

KWON M. (2004), One place after another: site-specific art and locational identity, Cambridge, The MIT Press.

LACY S. (ed.) (1995), Mapping the terrain: new genre public art, Seattle, Bay Press.

LEES L. (2001), "Towards a critical geography of architecture: the case of an ersatz colosseum", Ecumene (Cultural Geographies), 8, 1, DOI: 10.1177/096746080100800103, pp. 51-86.

LEFEBVRE H. (1991), The production of space, Oxford, Blackwell.

MASSEY D. \& ROSE G. (2003), Personal views: public art research project, Milton Keynes, Art Point Trust and Milton Keynes Council.

MCCARTHY J. (2006), "Regeneration of cultural quarters: public art for place image or place identity?", Journal of Urban Design, 11, 2, DOI: 10.1080/13574800600644118, pp. 243-262.

MCLUHAN M. (1964), Understanding media: the extensions of man, Cambridge, The MIT Press.

MILES M. (1997), Art, space and the city: public art and urban futures, London, Routledge.

MILES M. \& HALL T. (2005), Interventions: advances in art and urban futures (volume 4), Bristol, Intellect.

MITCHELL W. (ed.) (1992), Art and the public sphere, Chicago, The University of Chicago Press.

MOUFFE, C. (2000), The democratic paradox, London, Verso.

POLLOCK V. \& PADDISON R. (2010), “Embedding public art: practice, policy and problems", Journal of Urban Design, 15, 3, DOI: 10.1080/13574809.2010.487810, pp. 335-356.

POPKE J. (2007), “Geography and ethics: spaces of cosmopolitan responsibility”, Progress in Human Geography, 31, 4, DOI: 10.1177/0309132507077090, pp. 509-518.

REMESAR A. (ed.) (2005), Urban regeneration. A challenge for public art, Barcelona, University of Barcelona.

RANCIÈRE J. (2009), The emancipated spectator, London, Verso.

RENDELL J. (2000), "Public art: between public and private", in BENNETT S. \& BUTLER J. (eds.), Advances in art and urban futures: locality, regeneration and divers[c]ities, Bristol, Intellect, pp. 19-26.

ROBERTS M. \& MARSH C. (1995), "For art's sake: public art, planning policies and the benefits for commercial property", Planning Practice and Research, 10, 2, DOI: 10.1080/02697459550036702, pp. 189-198. 
ROTTERDAM MARKETING/VVV (2007), “Architecture in Rotterdam: about Rotterdam”, http:// www.architectuurinrotterdam.nl/cms.php?cmsid=49\&lang=en

SENIE H. \& WEBSTER S. (eds.) (1998), Critical issues in public art: content, context, and controversy, Washington, Smithsonian Institution Press.

SHARP J. (2007), "The life and death of five spaces: public art and community regeneration in Glasgow”, Cultural Geographies, 14, 2, DOI: 10.1177/1474474007075363, pp. 274-292.

SHARP J., POLLOCK V. \& PADDISON R. (2005), "Just art for a just city: public art and social inclusion in urban regeneration”, Urban Studies, 42, 5/6, DOI: 10.1080/00420980500106963, pp. 1001-1023.

SMITH M., DAVIDSON J., CAMERON L. \& BONDI L. (2009), "Introduction: geography and emotion: emerging constellations", in Emotion, place and culture, Aldershot, Ashgate, pp. 1-20.

SOJA E. (1996), Thirdspace: journeys to Los Angeles and other real-and-imagined places, Oxford, Blackwell.

STUIVER M., VAN DER JAGT P., VAN ERVEN E. \& HOVING I. (2013), "The potentials of art to involve citizens in regional transitions: exploring a site-specific performance in Haarzuilens, the Netherlands", Community Development Journal, 48, 2, DOI: 10.1093/cdj/bss022, pp. 298-312.

VALENTINE G. (2008), “Living with difference: reflections on geographies of encounter”, Progress in Human Geography, 32, 3, DOI: 10.1177/0309133308089372, pp. 323-337.

WARNER M. (2002), Publics and counterpublics, New York, Zone Books.

ZEBRACKI M. (2011) "Does cultural policy matter in public-art production? The Netherlands and Flanders compared, 1945-present", Environment and Planning A, 43, 12, DOI: 10.1068/a44215, pp. 2953-2970.

ZEBRACKI M. (2012), “Engaging geographies of public art: indwellers, the 'Butt Plug Gnome' and their locale”, Social \& Cultural Geography, 13, 7, DOI: 10.1080/14649365.2012.723735, pp. 735-758.

ZEBRACKI M. (2013), "Beyond public artopia: public art as perceived by its publics”, GeoJournal, 78, 2, DOI: $10.1007 / \mathrm{s} 10708-011-9440-8$, pp. 303-317.

ZEBRACKI M., VAN DER VAART R. \& VAN AALST I. (2010), “Deconstructing public artopia: situating public-art claims within practice”, Geoforum, 41, 5, DOI: 10.1016/j.geoforum.2010.04.011, pp. 786-795.

\section{NOTES}

1. Although public art's dyad, oxymoronic ontology is fairly complex and has been extensively reflected upon by scholarship hitherto (cf. Mitchell, 1992; Miles, 1997; Rendell, 2000; Hein, 2006), public art can basically be considered permanent or temporary and physical, immaterial or virtual work of art designed for and situated in the open public sphere (cf. ibid.).

2. The participants in the workshop provided me with consent to use the discussions and resulting data for my ongoing research. I have processed the expert views anonymously in this paper. The perspectives that I selected for inclusion in this paper are not necessarily endorsements on my part.

3. As of writing (early 2014), the current economic crisis has significantly reduced the financial means of SIR (now made part of Rotterdam Centre for Visual Arts), hence queered the pitch for the continuation of the Rotterdam-based survey group on art and public space. 
4. For an overview of Rotterdam's international flagship public-art collection, see http:// www.sculptureinternationalrotterdam.nl/collectie/overzicht.php

5. Note that these publics, in this sense, include both experts and the audiences.

6. All quotes in this paper are translated from the Dutch.

\section{ABSTRACTS}

Previous scholarship on public art has surveyed - in a usually discursive and at times overly generalised mode - how experts assume or ascribe a plethora of roles and (mis)uses regarding art in various political, economic, social and cultural geographical contexts. Public-art studies, nevertheless, are still remiss in indicating how experts socially negotiate such capacities of public art within in-vivo micropublics (cf. Amin, 2002): the socio-culturally diverse (micro)sites of everyday encounter. This paper attempts to move beyond "representational" knowledges by engaging with experts' lived experiences of contemporary public art along socio-spatial scales of three conceptual anchor points: art, public space and audience. Based on participatory, expertled research (2012) in the context of Rotterdam, the paper analyses experts' lived "agonistic" encounters (Mouffe, 2000) subsistent in public-art practice. This practice ranges from the bodily experiential scale of the artist, enabler and user of public space to community mentalities and interventions, local cultural policy directions and state governmentalities and praxes. The empirical analysis reveals how the experts' socially negotiated images and imaginations of public art's roles and (mis)uses critically attend to artistic production, the consumption of public space and audience involvement in a socio-spatially interlaced and multiscalar fashion. The paper argues that the pursued non-representational method can be employed in research, policy and practice to raise deeper awareness within the expert sphere about everyday encounter with public art and ensuing issues of audiencing in particular.

La recherche sur l'art public a souvent décrit - de manière le plus souvent discursive et parfois trop généralisante - comment les experts supposent et attribuent quantité de rôles et (més)usages à l'art dans des contextes géographiques, politiques, économiques, sociaux et culturels variés. Ces analyses négligent toutefois la manière dont ces experts négocient socialement les potentialités de l'art public au sein des micropublics (cf. Amin, 2002) dans les (micro)sites de la rencontre quotidienne, lesquels varient en fonction du contexte socio-culturel. Cet article tente d'aller au-delà des connaissances sur les représentations, en envisageant l'expérience vécue de l'art public contemporain par les experts selon les perspectives sociospatiales de trois points d'ancrage conceptuels: l'art, l'espace public et le public. L'analyse repose sur un travail de recherche participatif et d'expertise mené à Rotterdam (2012), ayant pour objet le vécu des experts relatif aux rencontres « agonistes " (Mouffe, 2000) associées à la pratique de l'art public. Cette pratique concerne tant l'expérience corporelle des mentalités communautaires et des interventions par l'artiste, le facilitateur et l'utilisateur de l'espace public, que les politiques culturelles locales, les praxis et les idéologies gouvernementales. L'étude empirique révèle comment les représentations socialement négociées que possèdent les experts du rôle et des (més)usages de l'art public participent à la production artistique, à la consommation de l'espace public et à l'implication des publics, sur le plan socio-spatial et de façon multiscalaire. L'article soutient que la méthode mise en place, allant au-delà des représentations, peut être utilisée dans la recherche, la politique et la pratique afin de sensibiliser la sphère des experts à la 
confrontation quotidienne à l'art public, et plus spécifiquement aux questions liées à tout ce qui concerne le public.

INDEX

Mots-clés: art public, espace public, public, experts, échelle, recherche participative, Rotterdam Keywords: public art, public space, audience, scale, participatory research

\section{AUTHOR}

\section{MARTIN ZEBRACKI}

Lecturer (Assistant Professor) in Critical Human Geography, School of Geography, University of Leeds, M.M.Zebracki@leeds.ac.uk 